\title{
Boosting Abscopal Response to Radiotherapy with Sargramostim: A Review of Data and Ongoing Studies
}

\author{
Robyn Leary ${ }^{1}$, Robert B. Gardner ${ }^{1}$, Colleen Mockbee ${ }^{1}$, Debasish F. Roychowdhury ${ }^{1}$ \\ 1. Oncology, Partner Therapeutics, Lexington, USA
}

Corresponding author: Robyn Leary, robyn.leary@partnertx.com

\begin{abstract}
Drug development in oncology today routinely focuses on approaches that utilize the patients' immune system to destroy the malignancy. Combinatorial approaches of antineoplastic agents, both new and old, are being incorporated in the armamentarium of cancer treatments. The overarching goal of therapy remains the achievement of a complete and durable response with long term remission or cure. One approach in advancing treatment is aimed at strategies that improve immunological memory to induce long lasting immunity against the tumor. Although radiation therapy has not traditionally been thought to elicit an immunological effect, an increasing number of reports document the induction of an immune response against a tumor that kills cancer cells distant to the original site of treatment after local irradiation to a tumor. This phenomenon is called an abscopal effect. Since radiation alone is rarely associated with such a response, it is being combined with immuno-oncology drugs in an attempt to enhance response. One such strategy combines sargramostim, a recombinant human granulocyte macrophage colony stimulating factor (rhu GM-CSF), with radiotherapy. GM-CSF is a cytokine secreted by multiple cells types that promotes maturation of dendritic cells and enables the presentation of tumor-associated antigens to generate a T-cell response. This review article discusses the outcomes of clinical trials and case reports examining the efficacy and safety of combining radiation therapy with this immunomodulatory agent. We will also examine future studies and challenges facing the translation of this therapeutic approach.
\end{abstract}

Received 12/18/2018

Review began 01/08/2019 Review ended 03/18/2019 Published 03/19/2019

๑) Copyright 2019

Leary et al. This is an open access article distributed under the terms of the Creative Commons Attribution License CC-BY 3.0., which permits unrestricted use, distribution, and reproduction in any medium, provided the original author and source are credited.
Categories: Radiation Oncology, Allergy/Immunology, Oncology

Keywords: myeloid growth factor, combination immunotherapy, cancer, immunotherapy, metastatic tumors, immuno-oncology, radiotherapy, pancreatic cancer, non-small cell lung cancer, melanoma

\section{Introduction And Background}

The synergy between immunotherapy and radiotherapy is being used to enhance therapeutic responses. One such strategy combines sargramostim, a recombinant human granulocyte macrophage colony stimulating factor (rhu GM-CSF) with radiotherapy (Figure 1). GM-CSF, a cytokine is involved in the production and maturation of a broad range of hematopoietic cells. The biological functions of GM-CSF are mediated through binding of its receptor (GM-CSFR) which triggers downstream signaling pathways such as Janus kinase-signal transducer and activator of transcription (JAK-STAT), phosphoinositide 3-kinase (PI3K), mitogen-activated protein kinase (MAPK), and nuclear factor-KB (NF-KB) signaling [1-3]. GM-CSF acts at both early and late stages of cellular differentiation and is thus necessary for the production of neutrophils, monocytes/macrophages, eosinophils, and myeloid dendritic cells [4-5]. This potent cytokine also facilitates the maturation and migration of dendritic cells to lymph nodes. Dendritic cells play an important role in the presentation of antigens and priming for primary and secondary $\mathrm{T}$ cell response [6]. Considering these effects, sargramostim has been used as a single agent as well as in combination both for antitumor treatment effects and as a vaccine in oncology trials [7]. The overarching goal of these therapeutic approaches combining sargramostim is the potential reversal of the host's immune tolerance to its own tumor-associated antigens to evoke long-lasting antitumor immunity.
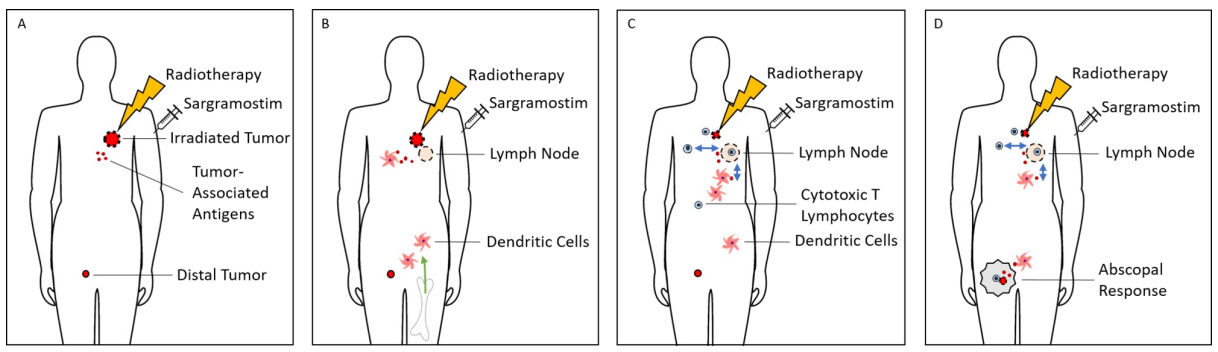

FIGURE 1: Induction of Abscopal Response by Radiotherapy and Sargramostim 
A) Radiotherapy with sargramostim is under investigation as a therapy for the treatment of solid tumors. Radiotherapy delivered to a tumor results in the release of tumor-associated antigens and the induction of a proinflammatory signaling cascade. B) Sargramostim supports myelopoiesis (green arrow) and enhances proliferation and differentiation of dendritic cells which process tumor-associated antigens from the irradiated tumor. C) Cross-presentation of tumor-associated antigens to CD8+ T cells by dendritic cells results the activation and migration of cytotoxic T lymphocytes (blue arrows) enhancing the antitumor response. D) The observation of circulating dendritic cells and cytotoxic $\mathrm{T}$ cells mounting an attack on distal tumors untreated by radiotherapy demonstrates an abscopal response.

Radiation therapy given locally can induce an immune response against a tumor that kills cancer cells distant to the original site of treatment [8]. This phenomenon is referred to as an abscopal response. In addition to inducing cytotoxic DNA damage, radiation releases immunostimulatory cytokines [9-10]. The release of DAMPs (damage-associated molecular patterns) acts as a danger signal to stimulate dendritic cell activation and antigen presentation inducing immunogenic cell death. Radiation bolsters CD8+ T cell infiltration and natural killer (NK) cell activity in the tumor microenvironment [11-12]. Increasingly, radiation therapy is being combined with immuno-oncology drugs to enhance the effect of these agents [13].

\section{Review}

\section{Clinical trials}

Golden and colleagues published the first Phase II study investigating radiotherapy in combination with sargramostim in patients with metastatic solid tumors that included an endpoint to assess abscopal response [14]. Subjects with metastatic cancer qualified for enrollment if they had a minimum of three distinct measurable tumors $\geqslant 1 \mathrm{~cm}$. All patients had adequate bone marrow function with an absolute neutrophil count greater than 1500 cells per $\mu \mathrm{L}$ and platelet concentration greater than 50,000 per $\mu \mathrm{L}$. These patients continued on the same chemotherapy or hormonal therapy they were on prior to their enrollment; however, dosing was adjusted according to radiotherapy in order to minimize toxicities. Patients were not included if they received immunotherapy in the four weeks prior to enrollment. Subjects with brain metastases were eligible for the trial; however, these lesions were not evaluated in the study.

A total of 41 patients with lung, breast, thymic, urothelial, ovarian, eccrine, or cervical cancer and confirmed metastatic cancer with stable or progressing disease were treated with concurrent radiation (35 Gy in ten fractions, over two weeks) and sargramostim ( $125 \mu \mathrm{g} / \mathrm{m} 2$ daily for two weeks, starting one week after the start of each course of radiotherapy). Lesions were treated sequentially, with the second course of therapy targeting a second distant metastatic site. Computed tomography (CT) scans evaluated patient response 7-8 weeks after the start of treatment.

The primary endpoint was to determine the proportion of patients with an abscopal response, as defined by a reduction of at least $30 \%$ in any measurable non-irradiated lesion $\geqslant 1 \mathrm{~cm}$. For this endpoint to be achieved, $\geqslant 20 \%$ of patients needed to exhibit an abscopal response. The secondary endpoints were to evaluate the safety and overall survival associated with abscopal responses. Lymphocytes were monitored by complete blood counts as an exploratory endpoint. The study is complete and registered with ClinicalTrials.gov [NCT02474186].

The treatment was well tolerated. No patients discontinued treatment due to the toxicity of the regimen, and no instances of dose reduction of sargramostim or radiation were required. Grade 3 or 4 toxicities primarily started during the first course of therapy, with the most common Grade 3 or 4 adverse events being fatigue (six patients) or hematological (10 patients) in nature.

Overall, the study met its prespecified margin for activity, with more than $20 \%$ of patients having an abscopal response. In $27 \%$ of patients, abscopal responses were observed and were predictive of improved overall survival (20.98 vs. 8.33 months). When patients were divided based on their type of response, the risk of death for non-responders was more than twice that of responders. Responses were observed in patients with lung cancer ( 4 of 18 patients) including two complete responses, breast cancer (5 of 14 patients), and thymic cancer ( 2 of 2 patients). The median follow-up was 5.62 years.

Differences in baseline hematological parameters were observed between subjects with and without an abscopal response, possibly indicating a subset of patients may respond better to this treatment strategy. Although this trial did not incorporate comprehensive profiling of immune cells, hematological parameters included baseline levels of hemoglobin, albumin, and white blood cell count. Abscopal responders presented with a lower baseline neutrophil to lymphocyte ratio than non-responders ( 2.29 vs 4.24$)$. No significant differences in the mean hemoglobin and albumin concentrations were observed. The possibility that neutrophils or other immunosuppressive constituents of the tumor microenvironment may limit immune responses warrants further investigation in future trials [15-16].

\section{Case reports}

Recently, two case reports documenting an abscopal response provide further evidence for combining 
sargramostim with radiotherapy [7,17]. A patient with metastatic pancreatic cancer treated with gemcitabine and paclitaxel albumin presented with metastases in the liver and right pleura in the presence of rising CA199. Treatment with tyrosine kinase inhibitor, apatinib was intolerable due to gastrointestinal side effects and further targeted therapy was refused [7]. The patient experienced jaundice and palliative radiotherapy given as a total dose of $45 \mathrm{~Gy}$ delivered in fifteen fractions for three weeks to alleviate abdominal pain caused by the primary tumor. Subcutaneous injections of sargramostim were given for 14 days, $(125 \mu \mathrm{g} / \mathrm{m} 2)$ daily for two weeks beginning one week after the initiation of radiotherapy to the end of treatment. Reduction of the primary tumor and metastases was achieved and stable disease documented by CT at one month and three months post therapy, suggesting this therapeutic approach warrants further research for the treatment of pancreatic cancer.

A case report described an abscopal response in a patient diagnosed with stage IIIB, unclassifiable non-small cell lung cancer (NSCLC) treated with local radiotherapy in combination with oncothermia and sargramostim [18]. The subject presented with a $9.5 \mathrm{~cm}$ cavitary lesion in right lobe with regional and metastatic lymph nodes. After refusing chemotherapy and requesting an alternative treatment option, radiation with a dose of $1.7 \mathrm{cGy}$ in 28 daily fractions for 5-6 treatments per week was followed by three oncothermia treatments post radiation. Two weeks after treatment, daily subcutaneous sargramostim injections followed for 10 days, $(250 \mu \mathrm{g} / \mathrm{m} 2$ daily). This treatment was well tolerated. Multiple metastatic lymph nodes distal from the site of radiation demonstrated nearly a complete remission. Some data suggest this approach could enhance the immune response by locally increasing tumor oxygenation, perfusion, natural killer cell activity and trafficking of dendritic cells to the lymph nodes. Hyperthermia may also assist in overcoming immune tolerance [19-21].

\section{Future directions}

Further research to understand the predictors of response to therapy and ways to overcome immune tolerance are necessary to improve patient outcomes. One suggestion by Golden et al. is to combine a checkpoint inhibitor with radiotherapy and sargramostim. The proof of concept for combining sargramostim with a checkpoint inhibitor was established in advanced melanoma. In a randomized Phase II trial, assessment of sargramostim in combination with ipilimumab in treating patients with unresectable stage III/IV melanoma showed a prolonged overall survival (HR=0.64, $\mathrm{p}=0.01 ; 17.5$ months vs 12.7 months, $\mathrm{p}=0.01)$. Patients were treated with ipilimumab $(10 \mathrm{mg} / \mathrm{kg}$, intravenously) every three weeks for four doses, then every 12 weeks, and were administered sargramostim $250 \mu \mathrm{g}$ subcutaneously on the first two weeks of each three-week cycle. Furthermore, the combination of sargramostim and ipilimumab resulted in lower toxicity compared with ipilimumab alone [22]. Like other cytokines, GM-CSF has both immune effector and regulatory functions and both of these effects may have important utilities in patients with cancer as was demonstrated with improved efficacy and reduced toxicity.

To get a better understanding of future studies investigating the combination of radiotherapy in conjunction with sargramostim, the ClinicalTrials.gov database was queried using the search terms: GM-CSF, GMCSF, Granulocyte-Macrophage Colony-Stimulating Factor, sargramostim and Leukine. This search identified 445 trials, which were then individually assessed to determine if the listed trial included radiation as treatment modality in each study (database accessed December 8, 2018). A total of eight ongoing clinical trials aiming to test the combination of radiotherapy in conjunction with GM-CSF were identified (Table 1). In most of the studies, abscopal response is not described as primary or secondary endpoint, and the majority of the studies do not evaluate the combination of radiotherapy and sargramostim with a checkpoint inhibitor.

\begin{tabular}{|c|c|c|c|c|c|c|c|c|}
\hline Trial ID & Title & Phase & Condition & Radiation & Intervention & $\begin{array}{l}\text { Primary } \\
\text { Endpoints }\end{array}$ & $\begin{array}{l}\text { Secondary } \\
\text { Endpoints }\end{array}$ & $\begin{array}{l}\text { Exploratory } \\
\text { Endpoints }\end{array}$ \\
\hline NCT02383212 & $\begin{array}{l}\text { Study of } \\
\text { REGN2810 (Anti- } \\
\text { PD-1) in Patients } \\
\text { With Advanced } \\
\text { Malignancies }\end{array}$ & 1 & $\begin{array}{l}\text { Multiple } \\
\text { Cancers }\end{array}$ & $\begin{array}{l}\text { Hypofractionated } \\
\text { Radiotherapy }\end{array}$ & $\begin{array}{l}\text { Chemotherapy } \\
\text { regimens containing } \\
\text { Cyclophosphamide, } \\
\text { Carboplatin, } \\
\text { Paclitaxel, } \\
\text { Pemetrexed and/or } \\
\text { Docetaxel, Anti-PD-1 } \\
\text { (REGN2810) and } \\
\text { Sargramostim }\end{array}$ & $\begin{array}{l}\text { AE, Dose } \\
\text { Limiting } \\
\text { Toxicities }\end{array}$ & $\begin{array}{l}\text { RECIST, } \\
\text { irRC }\end{array}$ & None \\
\hline NCT02623595 & $\begin{array}{l}\text { A Study of SBRT in } \\
\text { Combination With } \\
\text { rhGM-CSF for } \\
\text { Stage IV NSCLC } \\
\text { Patients Who }\end{array}$ & II & Lung Cancer & $\begin{array}{l}\text { SBRT } 50 \text { Gy/5F D } \\
1 \text { to D 5, } 21 \text { D } \\
\text { cycle }\end{array}$ & Recombinant GM-CSF & $\begin{array}{l}\text { Abscopal } \\
\text { Effect } \\
\text { Rate }\end{array}$ & $\begin{array}{l}\text { OS, } \\
\text { Incidence } \\
\text { (AE), PFS, } \\
\text { ORR, } \\
\text { Abscopal } \\
\text { Effect } \\
\text { Rate, } \\
\text { Incidence }\end{array}$ & $\begin{array}{l}\text { T Cell } \\
\text { Count, } \\
\text { Ratio of } \\
\text { Effector T } \\
\text { Cells: }\end{array}$ \\
\hline
\end{tabular}




\section{Cureus}

\begin{tabular}{|c|c|c|c|c|c|c|c|c|}
\hline & $\begin{array}{l}\text { Failed in Second- } \\
\text { line Chemotherapy }\end{array}$ & & & & & & $\begin{array}{l}\text { Treatment- } \\
\text { Related } \\
\mathrm{AE}, \\
\text { Immune } \\
\text { Related AE }\end{array}$ & $\begin{array}{l}\text { Regulatory } \\
\text { T Cells }\end{array}$ \\
\hline NCT02663440 & $\begin{array}{l}\text { Trial of } \\
\text { Hypofractionated } \\
\text { Intensity } \\
\text { Modulated } \\
\text { Radiation Therapy } \\
\text { With } \\
\text { Temozolomide and } \\
\text { Granulocyte- } \\
\text { Macrophage } \\
\text { Colony-Stimulating } \\
\text { Factor for Patients } \\
\text { With Newly } \\
\text { Diagnosed } \\
\text { Glioblastoma } \\
\text { Multiforme }\end{array}$ & II & Glioblastoma & $\begin{array}{l}\text { Hypofractionated } \\
\text { IMRT }\end{array}$ & $\begin{array}{l}\text { Temozolomide and } \\
\text { Recombinant GM-CSF }\end{array}$ & PFS & None & None \\
\hline NCT02677155 & $\begin{array}{l}\text { Sequential } \\
\text { Intranodal } \\
\text { Immunotherapy } \\
\text { Combined with } \\
\text { Anti-PD1 } \\
\text { (Pembrolizumab) } \\
\text { in Follicular } \\
\text { Lymphoma }\end{array}$ & $\|$ & Lymphoma & $\begin{array}{l}8 \text { Gy on D } 2 \text { of } 5 \\
\text { D cycle }\end{array}$ & $\begin{array}{l}\text { Pembrolizumab, } \\
\text { Rituximab and } \\
\text { Sargramostim }\end{array}$ & $\begin{array}{l}\text { ORR, } \\
\text { Change in } \\
\text { Tumor } \\
\text { Load }\end{array}$ & $\begin{array}{l}\text { DOR, PFS, } \\
\text { TTNT, OS, } \\
\text { Change in } \\
\text { Tumor } \\
\text { Volume, } \\
\text { Safety, } \\
\text { Antitumor } \\
\text { T cell } \\
\text { Responses } \\
\text { (Blood) }\end{array}$ & None \\
\hline NCT02976740 & $\begin{array}{l}\text { SBRT Combination } \\
\text { With rhGM-CSF } \\
\text { and Ta1 for Stage } \\
\text { IV NSCLC Patients } \\
\text { Who Failed in } \\
\text { Second-line } \\
\text { Chemotherapy }\end{array}$ & II & Lung Cancer & $\begin{array}{l}\text { SBRT } 50 \text { Gy/4- } \\
10 F \text { from D } 1 \text { to } \\
\text { D } 10\end{array}$ & $\begin{array}{l}\text { Thymosin Alpha } \\
\text { and Recombinant GM- } \\
\text { CSF }\end{array}$ & $\begin{array}{l}\text { Abscopal } \\
\text { Effect } \\
\text { Rate }\end{array}$ & $\begin{array}{l}\text { OS, } \\
\text { Incidence } \\
\text { AE, ORR, } \\
\text { Incidence } \\
\text { Immune- } \\
\text { Related AE }\end{array}$ & None \\
\hline NCT03113851 & $\begin{array}{l}\text { Abscopal Effect of } \\
\text { Radiation in } \\
\text { Combination With } \\
\text { rhGM-CSF for } \\
\text { Metastatic Non- } \\
\text { small Cell Lung } \\
\text { Cancer }\end{array}$ & II & Lung Cancer & $\begin{array}{l}3.5 \text { Gy/fraction; } \\
\text { total dose of } 35 \\
\text { Gy/ } 10 \text { fractions } \\
\text { over } 2 \text { Wks }\end{array}$ & Recombinant GM-CSF & $\begin{array}{l}\text { Abscopal } \\
\text { Effect } \\
\text { Rate }\end{array}$ & OS, PFS & None \\
\hline NCT03392545 & $\begin{array}{l}\text { Combination of } \\
\text { Immunization and } \\
\text { Radiotherapy for } \\
\text { Recurrent GBM }\end{array}$ & 1 & Glioblastoma & $\begin{array}{l}\text { Radiotherapy } \\
\text { Not Specified }\end{array}$ & $\begin{array}{l}\text { Poly I:C and } \\
\text { Recombinant GM-CSF }\end{array}$ & $\begin{array}{l}\text { Incidence } \\
\text { Treatment } \\
\text { Related } \\
\text { AE }\end{array}$ & OS, PFS & None \\
\hline NCT03489616 & $\begin{array}{l}\text { Chemotherapy } \\
\text { Combination With } \\
\text { Local } \\
\text { Radiotherapy and } \\
\text { rhGM-CSF for } \\
\text { Oligometastatic } \\
\text { Stage IV NSCLC } \\
\text { Patients }\end{array}$ & 11 & Lung Cancer & $\begin{array}{l}4 \text { Gy per time (or } \\
\text { BED }>45 G y \text { ) D } \\
2 \text { to } D 15 \text { in cycle } \\
\text { of } 21 D\end{array}$ & $\begin{array}{l}\text { Pemetrexed and } \\
\text { Recombinant GM-CSF }\end{array}$ & PFS & $\begin{array}{l}\text { Abscopal } \\
\text { Effect } \\
\text { Rate, OS }\end{array}$ & None \\
\hline
\end{tabular}

\section{TABLE 1: Ongoing Clinical Trials Combining Radiation and Sargramostim}

$\mathrm{AE}=$ Adverse Events, D = Day, DLT = Dose Limiting Toxicity, DOR = Duration of Response, GBM = Glioblastoma, IMRT = Intensity Modulated Radiotherapy, NSCLC $=$ Non-Small Cell Lung Cancer, ORR = Objective Response Rate, OS = Overall Survival, PFS = Progression Free Survival, rhGM-CSF = Recombinant Human Granulocyte Macrophage Colony Stimulating Factor, SBRT = Stereotactic Body Radiation Therapy, TTNT = Time 


\section{Cureus}

\section{Conclusions}

These studies and reports suggest the combination of radiation therapy with sargramostim may result in an abscopal response in patients with solid tumors, but further research is necessary to validate these findings. The comparison of overall survival for patients with or without an abscopal response is interesting; however, interpretation is difficult without control arms which were not previously included in the study design. Furthermore, without prospective monitoring, one cannot draw conclusions as to whether antitumor $\mathrm{T}$ cell responses are enhanced by this therapeutic approach. It is imperative to collect more information on the immunological and molecular phenotypes of abscopal responders vs non-responders. For example, immunosequencing approaches would provide investigators with a better picture as to what components of the tumor are being recognized. This could also assist in evaluating the extensiveness of the adaptive immune response. As previously described, cytotoxic T lymphocytes kill tumor cells by recognizing tumorassociated antigens presented with major histocompatibility complex (MHC) molecules. To characterize which antigens these $\mathrm{T}$ cells recognize, immunosequencing makes it possible to see the diversity of the $\mathrm{T}$ cell receptor repertoire. Analysis of $\mathrm{T}$ cell clonotypes which infiltrate a given lesion provides insight into the $\mathrm{T}$ cell response as well as a repertoire of response. Together, these data could provide us with key mechanistic insights into the potential synergy of GM-CSF and radiation. A carefully designed and executed study is an important next step to determine the potential of this therapeutic approach.

\section{Additional Information}

\section{Disclosures}

Conflicts of interest: In compliance with the ICMJE uniform disclosure form, all authors declare the following: Payment/services info: Med Communications, Inc. was paid for their assistance with figure modifying, reference formatting, and article submission services. Financial relationships: Robyn Leary, Robert Brent Gardner, Colleen Mockbee, Debasish Roychowdhury declare(s) employment from Partner Therapeutics. Partner Therapeutics manufactures and commercializes sargramostim. Other relationships: All authors have declared that there are no other relationships or activities that could appear to have influenced the submitted work.

\section{References}

1. Hercus TR, Thomas D, Guthridge MA, Ekert PG, King-Scott J, Parker MW, Lopez AF: The granulocytemacrophage colony-stimulating factor receptor: linking its structure to cell signaling and its role in disease. Blood. 2009, 114:1289-1298. 10.1182/blood-2008-12-164004

2. Hercus TR, Dhagat U, Kan WL, et al.: Signalling by the $\beta c$ family of cytokines . Cytokine Growth Factor Rev. 2013, 24:189-201. 10.1016/j.cytogfr.2013.03.002

3. Yan WL, Shen KY, Tien CY, Chen YA, Liu SJ: Recent progress in GM-CSF-based cancer immunotherapy . Immunotherapy. 2017, 9:347-360. 10.2217/imt-2016-0141

4. Metcalf D: Hematopoietic cytokines. Blood. 2008, 111:485-491. 10.1182/blood-2007-03-079681

5. Metcalf D: The colony-stimulating factors and cancer. Nat Rev Cancer. 2010, 10:425. 10.1038/nrc2843

6. van de Laar L, Coffer PJ, Woltman AM: Regulation of dendritic cell development by GM-CSF: molecular control and implications for immune homeostasis and therapy. Blood. 2012, 119:3383-3393. 10.1182/blood2011-11-370130

7. Formenti SC, Demaria S: Systemic effects of local radiotherapy . Lancet Oncol. 2009, 10:718-726. 10.1016/S1470-2045(09)70082-8

8. Demaria S, Ng B, Devitt ML, Babb JS, Kawashima N, Liebes L, Formenti SC: Ionizing radiation inhibition of distant untreated tumors (abscopal effect) is immune mediated. Int J Radiat Oncol Biol Phys. 2004, 58:862870. 10.1016/j.ijrobp.2003.09.012

9. Demaria S, Pilones KA, Vanpouille-Box C, Golden EB, Formenti SC: The optimal partnership of radiation and immunotherapy: from preclinical studies to clinical translation. Radiat Res. 2014, 182:170-181. 10.1667/RR13500.1

10. Demaria S, Golden EB, Formenti SC: Role of local radiation therapy in cancer immunotherapy . JAMA Oncol. 2015, 1:1325-1332. 10.1001/jamaoncol.2015.2756

11. Hlavata Z, Solinas C, De Silva P, Porcu M, Saba L, Willard-Gallo K, Scartozzi M: The abscopal effect in the era of cancer immunotherapy: a spontaneous synergism boosting anti-tumor immunity?. Target Oncol. 2018, 13:113-123. 10.1007/s11523-018-0556-3

12. Salama AKS, Postow MA, Salama JK: Irradiation and immunotherapy: from concept to the clinic . Cancer. 2016, 122:1659-1671. 10.1002/cncr.29889

13. Barker HE, Paget JT, Khan AA, Harrington KJ: The tumour microenvironment after radiotherapy: mechanisms of resistance and recurrence. Nat Rev Cancer. 2015, 15:409-425. 10.1038/nrc3958

14. Golden EB, Chhabra A, Chachoua A, et al.: Local radiotherapy and granulocyte-macrophage colonystimulating factor to generate abscopal responses in patients with metastatic solid tumours: a proof-ofprinciple trial. Lancet Oncol. 2015, 16:795-803. 10.1016/S1470-2045(15)00054-6

15. Combining GM-CSF with radiotherapy induces abscopal responses . Cancer Discovery. 2015, 5:794. Accessed: December 17, 2018: http://cancerdiscovery.aacrjournals.org/content/5/8/794.1. 10.1158/2159- 


\section{Cureus}

8290.CD-RW2015-121

16. Brix N, Tiefenthaller A, Anders H, Belka C, Lauber K: Abscopal, immunological effects of radiotherapy: narrowing the gap between clinical and preclinical experiences. Immunol Rev. 2017, 280:249-279.

10.1111/imr.12573

17. Shi F, Wang X, Teng F, Kong L, Yu J: Abscopal effect of metastatic pancreatic cancer after local radiotherapy and granulocyte-macrophage colony-stimulating factor therapy. Cancer Biol Ther. 2017, 18:137-141. 10.1080/15384047.2016.1276133

18. Yoon SM, Lee JS: Case of abscopal effect with metastatic non-small-cell lung cancer . Oncothermia J. 2012, 5:53-57. Accessed: December 17, 2018: https://oncotherm.com/sites/oncotherm/files/201707/Case of abscopal effect with metastatic non-small-cell lung cance....

19. Andocs G, Renner H, Balogh L, Fonyad L, Jakab C, Szasz A: Strong synergy of heat and modulated electromagnetic field in tumor cell killing. Strahlenther Onkol. 2009, 185:120-126. 10.1007/s00066-0091903-1

20. Shen RN, Lu L, Young P, Shidnia H, Hornback NB, Broxmeyer HE: Influence of elevated temperature on natural killer cell activity, lymphokine-activated killer cell activity and lecitin-dependent cytotoxicity of human umbilical cord blood and adult blood cells. Int J Radiat Oncol Biol Phys. 1994, 29:821-826. 10.1016/0360-3016(94)90571-1

21. Mahmood J, Shukla HD, Soman S, et al.: Immunotherapy, radiotherapy, and hyperthermia: a combined therapeutic approach in pancreatic cancer treatment. Cancers. 2018, 10:469. 10.3390/cancers10120469

22. Hodi FS, Lee S, Mcdermott DF, et al.: Ipilimumab plus sargramostim vs ipilimumab alone for treatment of metastatic melanoma: a randomized clinical trial. JAMA. 2014, 312:1744-1753. 10.1001/jama.2014.13943 